\title{
7-Chlorofolipastatin, an inhibitor of sterol 0 -acyltransferase, produced by marine-derived Aspergillus ungui NKH-007
}

\author{
Ryuji Uchida ${ }^{1}$, Kento Nakajyo ${ }^{1}$, Keisuke Kobayashi ${ }^{1}$, Taichi Ohshiro ${ }^{1}$, Takeshi Terahara ${ }^{2}$, Chiaki Imada ${ }^{2}$ \\ and Hiroshi Tomoda ${ }^{1}$
}

A new depsidone, named 7-chlorofolipastatin, and five known structurally related depsidones were isolated from the culture broth of the marine-derived fungus Aspergillus ungui NKM-007 by solvent extraction and HPLC using an octadecylsilyl column. The structure of 7-chlorofolipastatin was elucidated by various spectroscopic data including 1D and 2D NMR spectroscopy. 7-Chlorofolipastatin inhibited sterol $O$-acyltransferase (SOAT) 1 and 2 isozymes in cell-based and enzyme assays using SOAT1and SOAT2-expressing Chinese hamster ovary (CHO) cells.

The Journal of Antibiotics (2016) 69, 647-651; doi:10.1038/ja.2016.27; published online 16 March 2016

\section{INTRODUCTION}

The enzyme sterol $O$-acyltransferase (SOAT, also known as acylcoenzyme A:cholesterol acyltransferase), an endoplasmic reticulum membrane protein, plays important roles in cholesterol regulation in humans. ${ }^{1}$ SOAT may be a promising target for the development of new anti-atherosclerotic agents. Although pharmaceutical laboratories have identified a number of synthetic SOAT inhibitors, none have been successfully developed to date because of side effects or the lack/ absence of efficacy in clinical trials. ${ }^{2-5}$ Recent molecular biological studies revealed the existence of two SOAT isozymes, SOAT1 and SOAT2, with distinct functions. ${ }^{6-9}$ SOAT1 is ubiquitously expressed in all tissues and cells, whereas SOAT2 is expressed predominantly in the liver (hepatocytes) and intestine. ${ }^{10}$

Our group has an extensive experience in discovering SOAT inhibitors with a microbial origin in an enzyme assay using rat liver microsomes. ${ }^{11}$. After confirming the presence of two SOAT isozymes, we reexamined SOAT inhibitors in cell-based and enzyme assays utilizing Chinese hamster ovary (CHO) cells expressing African green monkey SOAT1 (SOAT1-CHO cells) and SOAT2 (SOAT2-CHO cells) to investigate the selectivity of inhibitors toward these isozymes. ${ }^{12,13}$ We have continued this screening program in consideration of the selectivity of candidate microbial cultures toward the SOAT isozymes in these assay systems. A new chlorinated depsidone, designated 7chlorofolipastatin (1; Figure 1), was recently isolated along with five known depsidones: folipostatin (2), ${ }^{14}$ unguinol (3),${ }^{15}$ 2-chlorounginol (4) $,^{16} 2,7$-dichlorounginol $(5)^{17}$ and nornidulin $(6)^{18}$ from the culture broth of the marine-derived fungus Aspergillus ungui NKH-007. The fermentation, isolation, structural elucidation and SOAT inhibitory activities of $\mathbf{1}$ to $\mathbf{6}$ have been described in the present study.

\section{RESULTS AND DISCUSSION}

\section{Isolation of 1 to 6}

The culture broth $(0.61)$ was treated with EtOH $(0.6 \mathrm{l})$ for $1 \mathrm{~h}$, and EtOH extracts were filtered to remove cell debris. After the concentration of extracts to remove $\mathrm{EtOH}$, the aqueous solution was adjusted to $\mathrm{pH} 9.0$ and extracted with EtOAc (0.61). The organic layer was dried over $\mathrm{Na}_{2} \mathrm{SO}_{4}$ and concentrated under reduced pressure to give brown materials $(307 \mathrm{mg})$. These materials were dissolved in a small amount of $\mathrm{MeOH}$ and purified by HPLC under the following conditions: column, CAPCELL PAK C18 (i.d. $20 \times 250 \mathrm{~mm}$; Shiseido, Tokyo, Japan); mobile phase, $50 \% \mathrm{CH}_{3} \mathrm{CN}$ containing $0.05 \% \mathrm{H}_{3} \mathrm{PO}_{4}$; flow rate, $8 \mathrm{ml} \mathrm{min}^{-1}$; detection, UV $210 \mathrm{~nm}$. Compounds 1 to 6 were eluted a peak with retention times of $78,41,22,34,55$ and $83 \mathrm{~min}$, respectively. Each fraction of the peak was collected and concentrated to remove $\mathrm{CH}_{3} \mathrm{CN}$. The aqueous solution was extracted with EtOAc and the organic layer was concentrated to dryness to give pure 1 (27.3 mg), $\mathbf{2}$ (19.3 mg), 3 (33.0 mg), 4 (26.0 mg), 5 (23.4 mg) and 6 $(15.7 \mathrm{mg})$ as white powders.

Structural elucidation of 1

The physicochemical properties of $\mathbf{1}$ are summarized in Table 1. In UV spectra, 1 showed absorption maxima at 226 and $278 \mathrm{~nm}$ in $\mathrm{MeOH}$. Broad OH absorption near $3414 \mathrm{~cm}^{-1}$, typical C-H $\left(\mathrm{CH}_{2}\right)$ stretching absorptions at 2924 and $2857 \mathrm{~cm}^{-1}$, carbonyl absorption at $1711 \mathrm{~cm}^{-1}$ and aromatic C-C stretch absorptions (for carbon-carbon

${ }^{1}$ Graduate School of Pharmaceutical Sciences, Kitasato University, Tokyo, Japan and ${ }^{2}$ Graduate School of Marine Science and Technology, Tokyo University of Marine Science and Technology, Tokyo, Japan

Correspondence: Professor H Tomoda, Graduate School of Pharmaceutical Sciences, Kitasato University, 5-9-1 Shirokane, Minato-ku, Tokyo 108-8641, Japan.

E-mail: tomodah@pharm.kitasato-u.ac.jp

Received 24 December 2015; revised 27 January 2016; accepted 9 February 2016; published online 16 March 2016 
<smiles>[R2]c1c([R])c2c(c([R3])c1O)C(=O)Oc1c(c(C)c(O)c([R4])c1/C(C)=C/C)O2</smiles>

$\begin{array}{llll}\mathrm{R} 1 & \mathrm{R} 2 & \mathrm{R} 3 & \mathrm{R} 4\end{array}$

7-Chlorofolipastatin (1)<smiles>[CH]C=C(C)C</smiles><smiles>CC</smiles>

Folipastatin (2)<smiles>[CH]C(C)=C(C)C</smiles><smiles>CC</smiles>

Unguinol (3)

2-Chlorounguinol (4)<smiles>CC</smiles>

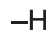

$-\mathrm{CH}_{3}$

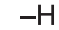

(4)

$-\mathrm{CH}_{3}$

$-\mathrm{CH}_{3}$

$-\mathrm{H}$

2,7-Dichlorounguinol (5)<smiles>C</smiles>
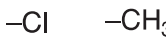

$-\mathrm{Cl}$

Nornidulin (6)

$-\mathrm{CH}_{3}$

$-\mathrm{Cl}$

$-\mathrm{Cl} \quad-\mathrm{Cl}$

Figure 1 Structures of 7-chlorofolipastatin (1) and related compounds 2 to 6.

Table 1 Physicochemical properties of 1

\begin{tabular}{|c|c|}
\hline Appearance & White powder \\
\hline Molecular formula & $\mathrm{C}_{23} \mathrm{H}_{23} \mathrm{O}_{5} \mathrm{Cl}$ \\
\hline Molecular weight & 414 \\
\hline \multicolumn{2}{|l|}{ HR-ESI-MS $(\mathrm{m} / \mathrm{z})$} \\
\hline Calcd & $437.1137[\mathrm{M}+\mathrm{Na}]^{+}$ \\
\hline Found & $437.1134[\mathrm{M}+\mathrm{Na}]^{+}$ \\
\hline$U V \lambda_{\max }^{\mathrm{CH}_{3} \mathrm{OH}} \mathrm{nm}(\log \varepsilon)$ & 226(2.19), 278(1.11) \\
\hline $\mathrm{IRv} \underset{\max }{\mathrm{KBr}} \mathrm{cm}^{-1}$ & $\begin{array}{c}3414,2924,2857,1711,1600 \\
1412,1267,1122,1078,822\end{array}$ \\
\hline$[\alpha]_{D}^{26}\left(\mathrm{c}=0.1, \mathrm{CH}_{3} \mathrm{OH}\right)$ & $0^{\circ}$ \\
\hline \multicolumn{2}{|l|}{ Solubility } \\
\hline Soluble & $\mathrm{CHCl}_{3}$, EtOAc, $\mathrm{CH}_{3} \mathrm{CN}, \mathrm{CH}_{3} \mathrm{OH}$ \\
\hline Insoluble & $\mathrm{H}_{2} \mathrm{O}$ \\
\hline
\end{tabular}

Abbreviation: $\mathrm{ESI}$, electrospray ionization.

bonds in the aromatic ring) at 1600 and $1412 \mathrm{~cm}^{-1}$ were observed in IR spectra. The electrospray ionization (EI)-MS of 1 showed an isotope pattern of $m / z 413[\mathrm{M}-\mathrm{H}]^{-}$and $415[\mathrm{M}+2-\mathrm{H}]^{-}$at a ratio of $3: 1$, indicating the presence of one chlorine atom in the molecule. The molecular formula $\mathrm{C}_{23} \mathrm{H}_{23} \mathrm{O}_{5} \mathrm{Cl}$ was assigned on the basis of its EI-MS $\left(\mathrm{m} / z 437.1134[\mathrm{M}+\mathrm{Na}]^{+}, \Delta-0.3 \mathrm{mmu}\right)$, indicating 12 degrees of unsaturation.

The ${ }^{1} \mathrm{H}$ and ${ }^{13} \mathrm{C}$ NMR spectra of 1 in DMSO- $d_{6}$ (Table 2) showed 23 proton and 23 carbon signals that were confirmed by an analysis of 2D NMR correlations. The multiplicity of the carbon signals was classified into five methyl carbons, three $s p^{2}$ methine carbons, one $s p^{2}$ nitrogenated methine carbon, eight $s p^{2}$ quaternary carbons, five $s p^{2}$ oxygenated quaternary carbons and one carbonyl carbon by an analysis of distorsionless enhancement by polarization transfer (DEPT) and heteronuclear multiple-quantum correlation (HMQC) data. The connectivity of proton and carbon atoms was established by HMQC (Table 2). As shown in Figure 2, the partial structures I and II were elucidated by ${ }^{1} \mathrm{H}-{ }^{1} \mathrm{H}$ correlation spectroscopy (COSY) spectra. The ${ }^{13} \mathrm{C}-{ }^{1} \mathrm{H}$ long-range couplings of ${ }^{2} \mathrm{~J}$ and ${ }^{3} \mathrm{~J}$ in the heteronuclear multiple bond correlation (HMBC) spectra (Figure 2) proved the presence of the following linkages. (1) Cross peaks from the $s p^{2}$ methine proton $\mathrm{H}-2(\delta 6.55)$ to the $s p^{2}$ quaternary carbon C-3 ( $\left.\delta 159.9\right)$, the $s p^{2}$ quaternary carbon C-4 $(\delta 113.3)$ and the $s p^{2}$ carbon C-11a $(\delta 110.0)$, from the hydroxyl proton OH-3 ( $\delta$ 10.54) to C-3 and the $s p^{2}$ carbon $\mathrm{C}-4$ ( $\delta$ 113.3) and from the methyl proton $4-\mathrm{CH}_{3}(\delta 2.04)$ to $\mathrm{C}-3, \mathrm{C}-4$ and the $s p^{2}$ oxygenated carbon $\mathrm{C}-4 \mathrm{a}(\delta 161.3)$ suggested the presence of a 3-hydroxy-4-methyl-1,4a,11a-pentasubtituted benzene ring. Further long-range couplings from the $s p^{2}$ methine proton $\mathrm{H}-2^{\prime}$ ( $\delta$ $5.34)$ to the methyl carbon $\mathrm{C}-4^{\prime}(\delta 17.5)$, from the methyl proton $\mathrm{H}_{3}-3$ ' $(\delta 1.64)$ to the $s p^{2}$ carbon $C-1^{\prime}(\delta 135.7)$ and from the methyl proton $\mathrm{H}_{3}-4^{\prime}\left(\delta\right.$ 1.77) to $\mathrm{C}-1^{\prime}$ and the $s p^{2}$ methine carbon C-2' ( $\delta$ 123.9) suggested the presence of an isobutyl group containing the partial structure I. This isobutyl group was connected to the benzene ring at C-1 by an observation of the ${ }^{3} J$ cross peaks from $\mathrm{H}-2^{\prime}$ and $\mathrm{H}_{3}-4^{\prime}$ to the carbon C-1 ( $\delta$ 148.4) and of the ${ }^{4} J$ cross peak from H-3'to C-1 in HMBC experiments. Furthermore, a ${ }^{4} J$ cross peak was observed from H-2 to the carbonyl carbon C-11 ( $\delta$ 163.0) in HMBC experiments, suggesting that this carbonyl carbon was connected to the benzene ring at C-11a. Thus, the ring $\mathrm{A}$ of $\mathbf{1}$ was elucidated as shown in Figure 2. (2) The ring B of 1 was elucidated from an analysis of the long-range couplings in $\mathrm{HMBC}$ in the same manner as described above. Long-range couplings from the hydroxyl proton $\mathrm{OH}-8$ ( $\delta 9.41)$ to the $s p^{2}$ carbons C-7 $(\delta 116.3)$ and C-9 $\left(\delta\right.$ 116.8) and the $s p^{2}$ oxygenated carbon $\mathrm{C}-8$ ( $\delta$ 148.7) and from the methyl proton $\mathrm{CH}_{3}-9$ ( $\delta$ 2.15) to C-8, C-9 and the $s p^{2}$ oxygenated carbon C-9a ( $\delta$ 142.4) were observed. Further long-range couplings from the $s p^{2}$ methine proton $\mathrm{H}-2^{\prime \prime}\left(\delta\right.$ 5.38) to the methyl carbon $\mathrm{C}-4^{\prime \prime}$ ( $\delta$ 17.3), from the methyl proton $\mathrm{H}_{3} 3^{\prime \prime}\left(\delta\right.$ 1.76) to the $s p^{2}$ carbon $\mathrm{C}-1^{\prime \prime}(\delta 129.8)$ and from the methyl proton $\mathrm{H}_{3}-4^{\prime \prime}(\delta$ 1.84) to C-1" and the $s p^{2}$ methine carbon C-2" ( $\delta$ 127.0) suggested the presence of an isobutyl group containing the partial structure II. This isobutyl group was connected to the quaternary carbon C-6 $(\delta 134.0)$ by the observation of ${ }^{3} \mathrm{~J}$ cross peaks from $\mathrm{H}-2^{\prime \prime}$ and $\mathrm{H}_{3}-4^{\prime \prime}$ to C-6 in HMBC experiments. A comparison of the NMR data between 1 and 2 revealed that the aromatic ${ }^{13} \mathrm{C}$ chemical sift values were very similar, whereas the $s p^{2}$ methine carbon at C-7 in 2 was replaced by a $s p^{2}$ fully substituted carbon in $\mathbf{1}$, indicating that ring $\mathrm{B}$ in 1 had a hexasubstituted benzene ring and the aromatic proton at C-7 of 2 was substituted by a chlorine atom in $\mathbf{1}$ (Figure 2). (3) The molecular formula and degrees of unsaturation of $\mathbf{1}$ indicated that the aromatic rings $\mathrm{A}$ and $\mathrm{B}$ were connected via an ether linkage between $\mathrm{C}-4 \mathrm{a}$ and $\mathrm{C}-5 \mathrm{a}$ and an ester bridge between C-9a and C-11, suggesting a depsidone skeleton with a central seven-membered ring C. Taken together, the structure of $\mathbf{1}$ was elucidated as shown in Figure 1, that fulfilled the molecular formula and degrees of unsaturation.

Inhibition of SOAT isozymes using SOAT1- and SOAT2-CHO cells Cell-based assay. The effects of $\mathbf{1}$ to $\mathbf{6}$ on cholesteryl ester (CE) synthesis were evaluated in a cell-based assay using SOAT1- and SOAT2-CHO cells. As shown in Table 3, 1 to 4 inhibited SOAT1 and SOAT2 isozymes with analogous $\mathrm{IC}_{50}$ values $(2.0-16 \mu \mathrm{M})$, giving selectivity index $\left(\log \left(\mathrm{IC}_{50}\right.\right.$ for $\left.\mathrm{SOAT} 1\right) /\left(\mathrm{IC}_{50}\right.$ for SOAT2) ) values $(-0.15$ to 0.88$)$ ranging between -1.00 and +1.00 (dual-type 
Table $2{ }^{1} \mathrm{H}$ and ${ }^{13} \mathrm{C}$ NMR chemical shifts of 1 and 2 in DMSO- $d_{6}$

\begin{tabular}{|c|c|c|c|c|c|c|c|c|c|c|c|c|}
\hline \multirow[b]{2}{*}{ Position } & \multicolumn{6}{|c|}{1} & \multicolumn{6}{|c|}{2} \\
\hline & $\delta_{C}$ & mult & $\delta_{H}$ & & mult & $J(H z)$ & $\delta_{C}$ & mult & $\delta_{H}$ & & mult & $J(H z)$ \\
\hline 1 & 148.4 & $\mathrm{~s}$ & & & & & 147.6 & $\mathrm{~s}$ & & & & \\
\hline 2 & 111.9 & $d$ & 6.55 & $1 \mathrm{H}$ & $\mathrm{s}$ & & 111.9 & $d$ & 6.53 & $1 \mathrm{H}$ & $\mathrm{s}$ & \\
\hline 3 & 159.9 & $\mathrm{~s}$ & & & & & 159.4 & $\mathrm{~s}$ & & & & \\
\hline 4 & 113.3 & $\mathrm{~s}$ & & & & & 113.4 & $\mathrm{~s}$ & & & & \\
\hline $4 a$ & 161.3 & $\mathrm{~s}$ & & & & & 161.6 & $\mathrm{~s}$ & & & & \\
\hline $5 a$ & 141.9 & $\mathrm{~s}$ & & & & & 141.7 & $\mathrm{~s}$ & & & & \\
\hline 6 & 134.0 & $\mathrm{~s}$ & & & & & 135.7 & $\mathrm{~s}$ & & & & \\
\hline 7 & 116.3 & $\mathrm{~s}$ & & & & & 111.0 & d & 6.39 & $1 \mathrm{H}$ & $\mathrm{s}$ & \\
\hline 8 & 148.7 & $\mathrm{~s}$ & & & & & 152.5 & $\mathrm{~s}$ & & & & \\
\hline 9 & 116.8 & $\mathrm{~s}$ & & & & & 114.8 & $\mathrm{~s}$ & & & & \\
\hline $9 a$ & 142.4 & s & & & & & 143.2 & s & & & & \\
\hline 11 & 163.0 & $\mathrm{~s}$ & & & & & 163.5 & $\mathrm{~s}$ & & & & \\
\hline $11 a$ & 110.0 & $\mathrm{~s}$ & & & & & 110.9 & s & & & & \\
\hline $1^{\prime}$ & 135.7 & $\mathrm{~s}$ & & & & & 133.5 & $\mathrm{~s}$ & & & & \\
\hline $2^{\prime}$ & 123.9 & $d$ & 5.34 & $1 \mathrm{H}$ & $\mathrm{dq}$ & $1.5,7.0$ & 123.8 & $d$ & 5.32 & $1 \mathrm{H}$ & $\mathrm{dq}$ & $1.5,6.7$ \\
\hline $3^{\prime}$ & 14.1 & $q$ & 1.64 & $3 \mathrm{H}$ & $\mathrm{dd}$ & $1.5,7.0$ & 13.8 & $q$ & 1.64 & $3 \mathrm{H}$ & $\mathrm{dd}$ & $1.5,6.7$ \\
\hline $4^{\prime}$ & 17.5 & $q$ & 1.77 & $3 \mathrm{H}$ & $d$ & 1.5 & 17.8 & $q$ & 1.77 & $3 \mathrm{H}$ & $d$ & 1.5 \\
\hline $1^{\prime \prime}$ & 129.8 & $\mathrm{~s}$ & & & & & 135.6 & $\mathrm{~S}$ & & & & \\
\hline $2^{\prime \prime}$ & 127.0 & $d$ & 5.38 & $1 \mathrm{H}$ & $\mathrm{dq}$ & $1.5,7.0$ & 125.1 & $d$ & 5.46 & $1 \mathrm{H}$ & $\mathrm{dq}$ & $1.5,6.7$ \\
\hline $3^{\prime \prime}$ & 13.8 & $q$ & 1.76 & $3 \mathrm{H}$ & $\mathrm{dd}$ & $1.5,7.0$ & 14.1 & $q$ & 1.72 & $3 \mathrm{H}$ & $\mathrm{dd}$ & $1.5,6.7$ \\
\hline $4^{\prime \prime}$ & 17.3 & $q$ & 1.84 & $3 \mathrm{H}$ & $d$ & 1.5 & 17.4 & $q$ & 1.97 & $3 \mathrm{H}$ & $d$ & 1.5 \\
\hline 4-Me & 8.5 & $q$ & 2.04 & $3 \mathrm{H}$ & $\mathrm{s}$ & & 8.3 & $q$ & 2.02 & $3 \mathrm{H}$ & $\mathrm{s}$ & \\
\hline 9-Me & 10.1 & $q$ & 2.15 & $3 \mathrm{H}$ & $\mathrm{s}$ & & 9.0 & $q$ & 2.03 & $3 \mathrm{H}$ & $\mathrm{s}$ & \\
\hline $3-\mathrm{OH}$ & & & 10.54 & $1 \mathrm{H}$ & $\mathrm{s}$ & & & & 10.42 & $1 \mathrm{H}$ & $\mathrm{s}$ & \\
\hline $8-\mathrm{OH}$ & & & 9.41 & $1 \mathrm{H}$ & $\mathrm{s}$ & & & & 9.65 & $1 \mathrm{H}$ & $\mathrm{s}$ & \\
\hline
\end{tabular}

The ${ }^{13} \mathrm{C}(100 \mathrm{MHz})$ and ${ }^{1} \mathrm{H}(400 \mathrm{MHz})$ spectra were taken on XL-400 NMR system (Agilent) in DMSO- $d_{6}$, and solvent peak was used as an internal standard at $2.49 \mathrm{ppm}$ for ${ }^{1} \mathrm{H}-\mathrm{NMR}$ and at $39.5 \mathrm{ppm}$ for ${ }^{13} \mathrm{C}-\mathrm{NMR}$.

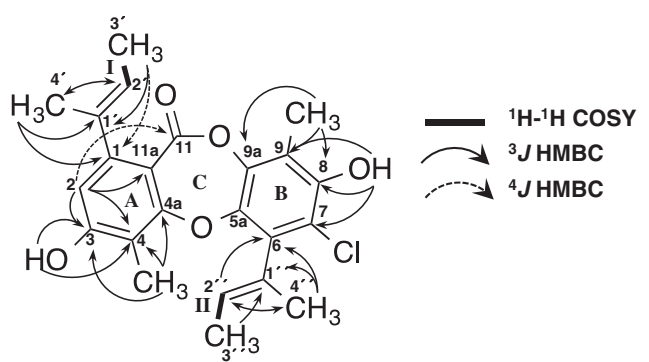

Figure 2 Key correlations in ${ }^{1} \mathrm{H}-{ }^{1} \mathrm{H}$ COSY and heteronuclear multiple bond correlation (HMBC) spectra of 7-chlorofolipastatin (1).

inhibition). ${ }^{12}$ Both 5 and $\mathbf{6}$ also showed very weak inhibition (40-50\% inhibition at 23-25 $\mu \mathrm{M}$ ) in both SOAT1- and SOAT2-CHO cells.

Enzyme assay. The inhibition of SOAT by $\mathbf{1}$ to $\mathbf{6}$ was evaluated in the enzyme assay using microsomes prepared from SOAT1- and SOAT2$\mathrm{CHO}$ cells. As shown in Table 3 , the $\mathrm{IC}_{50}$ and selectivity index values of $\mathbf{1}$ to $\mathbf{6}$ in the enzyme assay were consistent with those in the cellbased assay. Depsidones with no or one chloride in their molecules (1 to 4) exhibited dual-type SOAT inhibition, whereas those with two chlorides (5 and $\mathbf{6})$ had decreased inhibitory activity.

Inhibition of CE synthesis in mouse peritoneal macrophages The effects of 1 to $\mathbf{6}$ on CE synthesis (synthesized by SOAT1) were investigated in mouse peritoneal macrophages according to our established method. ${ }^{19} \mathrm{CE}$ accumulation in macrophages promotes atherosclerosis in arterial walls. ${ }^{20}$ Compounds 1 to 4 inhibited CE synthesis with $\mathrm{IC}_{50}$ values of 6.8, 12 and $19 \mu \mathrm{M}$, respectively (Table 3), consistent with those in SOAT1-CHO cells.

\section{Antimicrobial activity}

The antimicrobial activities of 1 to $\mathbf{6}$ (10 $\mu \mathrm{g}$ per disk), as determined by the agar diffusion assay, are summarized in Table 4 . All compounds exhibited weak antimicrobial activity against the Gram-positive bacteria, Bacillus subtilis, Staphylococcus aureus and Micrococcus luteus, but did not affect the growth of the Gram-negative bacteria, Escherichia coli and Pseudomonas aeruginosa or yeast Candida albicans.

\section{Conclusion}

In the present study, a new chlorinated depsidone, 7-chlorofolipastatin (1), was isolated together with five known depsidones, 2 to 6 , from the culture broth of a marine-derived Aspergillus strain. Compounds 1 to 4 moderately inhibited SOAT1 and SOAT2 isozymes (moderate dualtype SOAT inhibition).

\section{METHODS}

\section{General}

Various NMR spectra were obtained using $400 \mathrm{MHz}$ spectrometer (Agilent Technologies, Santa Clara, CA, USA). FAB-MS spectra were recorded on a JMS-700 Mstation (JEOL, Tokyo, Japan). Optical rotations were measured with a digital polarimeter (DIP-1000; JASCO, Tokyo, Japan). UV spectra were recorded on an 8453 UV-visible spectrophotometer (Agilent Technologies). IR 
Table 3 Effect of 1 to 6 on SOAT1 and SOAT2 activities in cell-based and enzyme-based assays

\begin{tabular}{|c|c|c|c|c|c|c|c|}
\hline \multirow[b]{3}{*}{ Compound } & \multicolumn{7}{|c|}{$I_{50}(\mu \mathrm{M})$ for $C E$ synthesis } \\
\hline & \multicolumn{4}{|c|}{ Cell-based assay ${ }^{b}$} & \multicolumn{3}{|c|}{ Enzyme-based assay ${ }^{b}$} \\
\hline & SOAT1 & SOAT2 & $S^{A}$ & Macrophage & SOAT1 & SOAT2 & $S I$ \\
\hline 1 & 3.2 & 4.5 & -0.15 & 6.8 & 6.5 & 19 & -0.47 \\
\hline 2 & 9.6 & 2.0 & 0.68 & 12 & 10 & 6.6 & 0.18 \\
\hline 3 & 16 & 2.1 & 0.88 & 19 & 27 & 10 & 0.43 \\
\hline 4 & $>27$ & 6.8 & $>0.60$ & $>27$ & $>69$ & 28 & $>0.39$ \\
\hline 5 & $>25$ & $>25$ & - & $>25$ & $>63$ & $>63$ & - \\
\hline 6 & $>23$ & $>23$ & - & $>23$ & $>58$ & $>58$ & - \\
\hline
\end{tabular}

Abbreviations: CE, capillary electrophoresis; $\mathrm{SI}$, selective index; SOAT, sterol $O$-acyltransferase. a SI $=\log \left(I C_{50}\right.$ for SOAT1 $) /\left(I C_{50}\right.$ for SOAT2)

${ }^{\mathrm{b}} \mathrm{N}=>3$.

Table 4 Antimicrobial activity of 1 to 6

\begin{tabular}{|c|c|c|c|c|c|c|}
\hline \multirow[b]{2}{*}{ Microorganism } & \multicolumn{6}{|c|}{ Inhibition zone (mm) } \\
\hline & 1 & 2 & 3 & 4 & 5 & 6 \\
\hline Bacillus subtilis $\mathrm{PCl} 219$ & 8 & 9 & - & - & 10 & 8 \\
\hline Staphylococcus aureus FDA209P & - & 8 & 8 & 9 & 16 & 9 \\
\hline Micrococcus luteus KB212 & 7 & 8 & 15 & 11 & 11 & 14 \\
\hline Escherichia coli JM109 & - & - & - & - & - & 一 \\
\hline Pseudomonas aeruginosa IF012689 & - & - & - & - & - & - \\
\hline Candida albicans ATCC90029 & - & - & - & - & - & - \\
\hline
\end{tabular}

Antimicrobial activity was measured by the agar diffusion method using paper disks (6 mm thin disk).

spectra were recorded on a Fourier transform an FT-710 spectrometer (Horiba, Kyoto, Japan).

\section{Materials}

The $\left[1-{ }^{14} \mathrm{C}\right]$ Oleic acid $\left(1.85 \mathrm{GBq} \mathrm{mmol}^{-1}\right)$ was purchased from PerkinElmer (Waltham, MA, USA). Fetal bovine serum was purchased from Biowest (Nuaille, France). Dulbecco's modified Eagle's medium and Hank's buffered salt solution were purchased from Nissui Pharmaceutical (Tokyo, Japan). GIT medium was from Nippon Seiyaku (Tokyo, Japan). Penicillin $\left(10000\right.$ units $\left.\mathrm{ml}^{-1}\right)$, streptomycin $\left(10000 \mathrm{mg} \mathrm{ml}^{-1}\right)$ and glutamine (200 mm) solution were from Invitrogen (Carlsbad, CA, USA). Phosphatidylcholine, phosphatidylserine, dicetylphosphate, cholesterol, Ham's F-12 medium, malachite green oxalate and $\mathrm{BFA}_{1}$ were purchased from Sigma-Aldrich (St Louis, MO, USA). Perchloric acid and Triton X-100 were purchased from Wako (Osaka, Japan).

\section{Fungal strain and identification}

The fungal strain NKH-007 was isolated from soil that was collected from the Suruga Bay, Japan $\left(138^{\circ} 18.1207^{\prime} \mathrm{E}, 34^{\circ} 22.4813^{\prime} \mathrm{N}\right)$ at a depth of $331 \mathrm{~m}$ on 15 July 2013. In a BLAST search from the NCBI (National Center for Biotechnology Information), NKH-007 had 100\% similarity with the rDNA sequence of the internal transcribed spacer region of Aspergillus ungui SRRC 344 (GenBank accession number AY373872). ${ }^{21}$ Therefore, the strain NKH-007 was identified with Aspergillus ungui.

\section{Fermentation of Aspergillus ungui NKH-007}

A loopful of spores of strain NKH-007 was inoculated into $100 \mathrm{ml}$ seed medium consisting of $2.4 \%$ potato dextrose broth (Becton Dickinson and Company, Franklin Lakes, NJ, USA) and $0.1 \%$ agar (adjusted to pH 6.0 before sterilization) in a 500-ml Erlenmeyer flask. The inoculated Erlenmeyer flask was incubated in a rotary shaker (200 r.p.m.) at $27^{\circ} \mathrm{C}$ for 5 days to obtain the seed culture. In order to produce 1 , the culture was initiated by transferring $1 \mathrm{ml}$ seed culture into each of six 500-ml culture bottles (AS ONE, Osaka, Japan) containing $100 \mathrm{ml}$ production medium (2.4\% potato dextrose broth, adjusted to $\mathrm{pH} 6.0$ before sterilization). Fermentation was carried out under static conditions at $27^{\circ} \mathrm{C}$ for 14 days.

\section{Structural determination of 2 to 6}

Using spectral data including ${ }^{1} \mathrm{H}$ NMR, ${ }^{13} \mathrm{C}$ NMR and MS, and the search results of SciFinder Scholar, 2 to $\mathbf{6}$ were identified as the known depsidones folipastatin (2), unguinol (3), 2-chlorounginol (4), 2,7-dichlorounginol (5) and nornidulin (6), respectively (Figure 1).

\section{Cell culture}

Two cell lines, CHO cells expressing SOAT1 and SOAT2 isozymes of African green monkey (SOAT1- and SOAT2-CHO cells, respectively), ${ }^{13}$ were kind gifts from Dr LL Rudel (Wake Forest University, Winston-Salem, NC, USA). Cells were maintained as described previously. ${ }^{12}$

\section{Assays for SOAT activity in SOAT1- and SOAT2-CHO cells}

Assays for SOAT1 and SOAT2 activities using SOAT1- and SOAT2-CHO cells were carried out by our established method. ${ }^{12}$ Briefly, SOAT1- or SOAT2-CHO cells $\left(1.25 \times 10^{5}\right.$ cells in $250 \mu \mathrm{l}$ of medium) were cultured in a 48 -well plastic microplate in the culture medium described above and allowed to recover overnight at $37^{\circ} \mathrm{C}$ in $5 \% \mathrm{CO}_{2}$. The assays were conducted with cells that were at least $80 \%$ confluent. Following overnight recovery, the test sample $(2.5 \mu \mathrm{l}$ $\mathrm{MeOH}$ solution) and $\left[1-{ }^{14} \mathrm{C}\right]$ oleic acid $(5 \mu l \quad 10 \%$ EtOH/phosphate-buffered saline solution, $1 \mathrm{nmol}, 1.85 \mathrm{KBq}$ ) were added to each culture. The medium was removed after a 6 -h incubation at $37{ }^{\circ} \mathrm{C}$ in $5 \% \mathrm{CO}_{2}$, and the cells in each well were washed twice with phosphate-buffered saline. The cells were lysed by adding $0.25 \mathrm{ml}$ of $10 \mathrm{~mm}$ Tris- $\mathrm{HCl}(\mathrm{pH} 7.5)$ containing $0.1 \%(\mathrm{w} / \mathrm{v})$ sodium dodecyl sulfate, and $\left[{ }^{14} \mathrm{C}\right] \mathrm{CE}$ was analyzed with a BAS2000 analyzer (Fuji Film, Tokyo, Japan). In this cell-based assay, $\left[{ }^{14} \mathrm{C}\right] \mathrm{CE}$ was produced by the reaction of SOAT1 or SOAT2. SOAT inhibitory activity $(\%)$ was defined as $\left(\left[1-{ }^{14} \mathrm{C}\right] \mathrm{CE}-\right.$ drug $/\left[{ }^{14} \mathrm{C}\right] \mathrm{CE}$-control $) \times 100$. The $\mathrm{IC}_{50}$ value was defined as the drug concentration that inhibited biological activity by $50 \%$.

Assay for SOAT activity in microsomes from SOAT1- and SOAT2CHO cells

SOAT1 and SOAT2 activities were determined using microsomes prepared from SOAT1- and SOAT2-CHO cells as the enzyme source. ${ }^{12}$ Briefly, an assay mixture containing $2.5 \mathrm{mg} \mathrm{ml}^{-1}$ bovine serum albumin in buffer A and $\left[1-{ }^{14} \mathrm{C}\right]$ oleoyl-CoA $(20 \mu \mathrm{m}, 3.7 \mathrm{kBq})$ together with a test sample (added as a $10 \mu \mathrm{l}$ methanol solution), and the SOAT1 or SOAT2 microsomal fraction (150 or $10 \mu \mathrm{g}$ of protein, respectively) in a total volume of $200 \mu \mathrm{l}$ were incubated at $37^{\circ} \mathrm{C}$ for $5 \mathrm{~min}$. The reaction was started by adding $\left[1-{ }^{14} \mathrm{C}\right]$ oleoyl-CoA and stopped by adding $1.2 \mathrm{ml}$ of $\mathrm{CHCl}_{3} / \mathrm{MeOH}(2: 1)$. The product $\left[{ }^{14} \mathrm{C}\right] \mathrm{CE}$ was extracted by the method of Bligh and Dyer. ${ }^{22}$ After the organic solvent was removed by evaporation, lipids were separated on a TLC plate and the radioactivity of $\left[{ }^{14} \mathrm{C}\right] \mathrm{CE}$ was measured as described above.

\section{Assay for CE synthesis in mouse peritoneal macrophages}

The assay for $\mathrm{CE}$ synthesis from $\left[{ }^{14} \mathrm{C}\right]$ oleic acid was carried out according to a previously described method. ${ }^{19}$ Briefly, mouse peritoneal macrophages $\left(5.0 \times 10^{5}\right.$ cells per $0.25 \mathrm{ml}$ of medium B (containing Dulbecco's modified Eagle's medium supplemented with $8.0 \%(\mathrm{v} / \mathrm{v})$ lipoprotein-deficient serum, penicillin $\left(100\right.$ units $\left.\mathrm{ml}^{-1}\right)$ and streptomycin $\left(100 \mathrm{mg} \mathrm{ml}^{-1}\right)$ ) were cultured in each well of a 48-well plastic microplate with a test compound (in $2.5 \mu \mathrm{l}$ of $\left.\mathrm{CH}_{3} \mathrm{CN}\right)$ and liposomes $(10.0 \mu \mathrm{l}, 1.0 \mu \mathrm{mol}$ phosphatidylcholine, $1.0 \mu \mathrm{mol}$ phosphatidylserine, $0.20 \mu \mathrm{mol}$ dicetylphosphate and $1.5 \mu \mathrm{mol}$ cholesterol, suspended in $1.0 \mathrm{ml}$ of $0.30 \mathrm{M}$ glucose $)$ together with $\left[{ }^{14} \mathrm{C}\right]$ oleic acid $(5.0 \mu \mathrm{l}$ $(1.85 \mathrm{kBq})$ in $10 \%$ ethanol/phosphate-buffered saline solution). Following a 14-h incubation, cellular lipids were extracted to measure the radioactivity of $\left[{ }^{14} \mathrm{C}\right] \mathrm{CE}$ according to the same method as described above. 


\section{Antimicrobial activity}

The antimicrobial activity of a sample against six species of microorganism was measured by the agar diffusion method using paper disks. Media for microorganisms were as follows: nutrient agar (Sanko Junyaku, Tokyo, Japan) for B. subtilis PCI219, S. aureus FDA209P, M. luteus KB212, E. coli JM109 and $P$. aeruginosa IFO12689, and medium composed of $1.0 \%$ glucose, $0.50 \%$ yeast extract and $0.80 \%$ agar for C. albicans ATCC90029. A paper disk (i.d. 6 mm; Toyo Roshi Kaisha, Tokyo, Japan) containing a sample $(10 \mu \mathrm{g})$ was placed on the agar plate. Bacteria were incubated at $37^{\circ} \mathrm{C}$ for $24 \mathrm{~h}$. C. albicans was incubated at $27^{\circ} \mathrm{C}$ for $48 \mathrm{~h}$. Antimicrobial activity was expressed as the diameter $(\mathrm{mm})$ of the inhibitory zone.

\section{CONFLICT OF INTEREST}

The authors declare no conflict of interest.

\section{ACKNOWLEDGEMENTS}

We thank Ms N Sato and Dr K Nagai, School of Pharmacy, Kitasato University, for measurements of mass and NMR spectra. This work was supported by JSPS KAKENHI Grant Number 26253009 (to HT).

1 Rudel, L. L., Lee, R. G. \& Cockman, T. L. Acyl coenzyme A: cholesterol acyltransferase types 1 and 2: structure and function in atherosclerosis. Curr. Opin. Lipidol. 12, 121-127 (2001).

2 Alegret, M., Llaverias, G. \& Silvestre, J. S. Acyl coenzyme A:cholesterol acyltransferase inhibitors as hypolipidemic and antiatherosclerotic drugs. Methods Find. Exp. Clin. Pharmacol. 26, 563-586 (2004).

3 Tardif, J. C. et al. Effects of the acyl coenzyme A:cholesterol acyltransferase inhibitor avasimibe on human atherosclerotic lesions. Circulation 110, 3372-3377 (2004).

4 Nissen, S. E. et al. Effect of ACAT inhibition on the progression of coronary atherosclerosis. N. Engl. J. Med. 354, 1253-1263 (2006).

5 Meuwese, M. C. et al. ACAT inhibition and progression of carotid atherosclerosis in patients with familial hypercholesterolemia: the CAPTIVATE randomized trial. JAMA 301, 1131-1139 (2009).

6 Chang, C. C., Huh, H. Y., Cadigan, K. M. \& Chang, T. Y. Molecular cloning and functional expression of human acyl-coenzyme A:cholesterol acyltransferase cDNA in mutant Chinese hamster ovary cells. J. Biol. Chem. 268, 20747-20755 (1993).
7 Anderson, R. A. et al. Identification of a form of acyl-CoA:cholesterol acyltransferase specific to liver and intestine in nonhuman primates. J. Biol. Chem. 273, 26747-26754 (1998)

8 Cases, S. et al. ACAT-2, a second mammalian acyl-CoA:cholesterol acyltransferase. Its cloning, expression, and characterization. J. Biol. Chem. 273, 26755-26764 (1998).

9 Oelkers, P., Behari, A., Cromley, D., Billheimer, J. T. \& Sturley, S. L. Characterization of two human genes encoding acyl coenzyme A:cholesterol acyltransferase-related enzymes. J. Biol. Chem. 273, 26765-26771 (1998).

10 Parini, P. et al. ACAT2 is localized to hepatocytes and is the major cholesterolesterifying enzyme in human liver. Circulation 110, 2017-2023 (2004).

11 Tomoda, H. \& Ōmura, S Potential therapeutics for obesity and atherosclerosis: inhibitors of neutral lipid metabolism from microorganisms. Pharmacol. Ther. 115, 375-389 (2007).

12 Ohshiro, T., Rudel, L. L., Ōmura, S. \& Tomoda, H Selectivity of microbial acyl-CoA:cholesterol acyltransferase inhibitors toward isozymes. J. Antibiot. 60, 43-51 (2007).

13 Lada, A. T. et al. Identification of ACAT1- and ACAT2-specific inhibitors using a novel, cell-based fluorescence assay: individual ACAT uniqueness. J. Lipid Res. 45, 378-386 (2004).

14 Hamano, K. et al. Folipastatin, a new depsidone compound from Aspergillus unguis as an inhibitor of phospholipase A2. Taxonomy, fermentation, isolation, structure determination and biological properties. J. Antibiot. 45, 1195-1201 (1992).

15 Feighner, S. D., Salituro, G. M., Smith, J. L. \& Tsou, N. N. Unguinol and analogs are animal growth permittants. US patent 5,350,763 (1994).

16 Kawahara, N., Nakajima, S., Satoh, Y., Yamazaki, M. \& Kawai, K. Studies on fungal products. XVIII.: isolation and structures of a new fungal depsidone related to nidulin and a new phthalide from Emericella unguis. Chem. Pharm. Bull. 36, 1970-1975 (1988).

17 Sureram, S. et al. Depsidones, aromatase inhibitors and radical scavenging agents from the marine-derived fungus Aspergillus unguis CRI282-03. Planta. Med. 78 582-588 (2012).

18 Dean, F. M., Roberts, J. C. \& Robertson, A. Chemistry of fungi. XXII. Nidulin and nornidulin (ustin): chlorine-containing metabolic products of Aspergillus nidulans. J. Chem. Soc. (1954)1432-1439 (1954).

19 Namatame, I., Tomoda, H., Arai, H., Inoue, K. \& Ōmura, S Complete inhibition of mouse macrophage-derived foam cell formation by triacsin C. J. Biochem. 125 319-327 (1999).

20 Ouimet, M. \& Marcel, Y. L. Regulation of lipid droplet cholesterol efflux from macrophage foam cells. Arterioscler. Thromb. Vasc. Biol. 32, 575-581 (2012).

21 Haugland, R. A., Varma, M., Wymer, L. J. \& Vesper, S. J Quantitative PCR analysis of selected Aspergillus, Penicillium and Paecilomyces species. Syst. Appl. Microbiol. 27, 198-210 (2004).

22 Bligh, E. G. \& Dyer, W. A rapid method of total lipid extraction and purification. Can. J. Biochem. Physiol. 37, 911-917 (1959). 